\title{
The Importance of European Funded Projects for the Development of a Tourist Destination Case study - North-West Region of Romania (North Transylvania)
}

\author{
Anamaria - Cătălina Radu, Andra Ileana Dobrescu, Mihai Cristian Orzan \\ and Larisa Boboc
}

The Bucharest University of Economic Studies, Bucharest, Romania,

Correspondence should be addressed to: Anamaria - Cătălina Radu; anamaria_radu15@yahoo.com

Received date: 2 October 2014; Accepted date: 17 December 2014; Published date: 15 September 2015

Academic Editor: Silviu Beciu

Copyright (C) 2015. Anamaria - Cătălina Radu, Andra lleana Dobrescu, Mihai Cristian Orzan and Larisa Boboc. Distributed under Creative Commons CC-BY 4.0

\begin{abstract}
The European funded projects are mainly aimed at the development of the activity sector where they are implemented. In tourism, these projects aim most of the time either at developing some tourist destinations, rehabilitation of certain tourist sights, or at developing certain elements that contribute to the improvement of the activity at the destination level. The investments made in this sector often lead to the modification of the marketing activities performed at the destination level. This paper aims to determine the importance of European funded projects in the development of a tourist region. The research aims to determine the tourists' opinion regarding how the results obtained from the current projects at the North-West Region of Romania (Northern Transylvania) are used. The multivariate analysis was aimed at determining the main features considered by the respondents to be relevant when considering the role of EU projects in developing the tourist destination. The data were processed using IBM program SPSS Statistics 20.
\end{abstract}

Keywords: online marketing, tourism destination, European funds;

\section{Introduction}

The European Union supports in financial terms both the Member States and those which are in adjacent geographical areas through the various programs and financial instruments. For this reason, an effective collaboration both within the European Union and between it and the possible project beneficiaries (Christiansen, T. 2001) is necessary. A collaboration between both parties contributes to the good running of the

Cite this Article as: Anamaria - Cătălina Radu, Andra Ileana Dobrescu, Mihai Cristian Orzan and Larisa Boboc (2015), " The Importance of European Funded Projects for the Development of a Tourist Destination Case study - North-West Region of Romania (North Transylvania)," Journal of Economic Studies and Research, Vol. 2015 (2015), Article ID 780380, DOI: 10.5171/2015. 780380. 
activity and getting remarkable results in the field in which they are implemented.

In Romania, the European funds are considered to be the most important instruments for the economic and regional development of the country. Considering the key objectives existing at the European Union level, Romania tries permanently to use the resources obtained from the funding either for the promotion of the economic growth at the regional level, or for the consolidation of the competitiveness and increase of labour force employment or for the decrease of the regional disparities existing at the country level. (fonduri-ue.ro)

The European funded projects in the field of tourism aim at supporting all the activities undertaken in this activity sector, with the aim of promoting the natural and anthropogenic potential existing in the tourism destinations. The implementation and development of certain projects funded from the European funds in the field of tourism was possible largely because of Romania's tourism potential. Thus, over the time, it was remarked that this activity sector is the most important for any country; it contributes directly to its economic growth. The implementation of certain projects which aim either at developing certain destinations or the rehabilitation of sightseeing area leading to improved economic activity carried out in the respective region.

The advantages obtained by the development of the tourist activity in a destination are multiple. The investments made through the implementation and completion of a project funded under European funds may result, subsequently, either in increasing jobs in the area, local economic growth in the region / area where investment was made, increasing the number of tourists visiting the destination, increasing the consumption of tourist products in the region, or developing complementary sectors, such as transport. In this way, the tourism sector through projects funded under the European funds contributes to the competitiveness increase and macro- destination development - Romania (finantare.ro).

The European projects that are developed in Romania, aim on the one hand at the development of the country as a whole, and on the other hand, at the development of the existing micro-destinations inside it. The projects implemented were mainly aimed at increasing the destinations' visibility among tourists. In order to reach the objectives developed by such a project, a series of investments were made, which aimed at achieving predetermined target points. By them, Romania can build the necessary basis to develop a strong country brand that can be continuously strengthened by developing regional brands. (fonduri-structurale.ro).

\section{The role of the European funded projects in the marketing activity developed at the tourist destination level}

The European funded projects aimed at developing the tourist areas and highlighting natural and anthropogenic potential existing at their level (Stancioiu et al, 2011). By the creation and implementation of such projects, both the promotion of the region as a whole and the development of marketing activity at the destination level (through the marketing mix) are made. Thus, there are a number of improvements in the products offered, the prices charged, the way of achievement of distribution, and ways for the promotion (Sarker et. al, 2012).

By the investments made in the region/area, the tourist products can be made consistent with the tourists' needs and demands. Thus, if before carrying out the investment, the tourist destination is only oriented to a specific target audience, following the development of such projects, the products made at the destination can be directed to other consumer segments. These products developed at a destination level must be consistent on the one hand with the needs of consumers, and on the other hand, with the natural and artificial potential that the destination in question has. 
Regarding the changes that occur in the price policy, we should mention that in tourism this component depends on both the activities carried out in the external area and the way in which tourists are willing to allocate a certain amount of money to purchase products/tourist services. The European Union funded projects without major changes in terms of price policy practiced in the area/region where the investment was made. The rehabilitation of certain sights through projects funded under European funds can cause the economic agents to select the distribution of tourist products that are marketed either for a direct distribution or for a distribution through intermediaries. Most times, the investments made in certain areas of interest, determine the major travel agencies to focus its activity towards these areas, trading tourist products/services existing here.

The projects funded under the EU funds put their mark on the modality of achieving the promotion in areas where investments were made. Thus, according to the results obtained after the completion of projects in a certain tourist destination can be developed to promote both traditional means (creating brochures, leaflets, catalogues, tourist information centers, etc.) also through online means (creating specialized sites, blogs, forums, social networking pages, etc.)

The online area provides tourists with the opportunity to communicate remotely (Orzan, 2001) and to find a range of information related to products sold to the destination. In this way, the digital environment enables marketers to consider, in addition to the four components of the marketing mix (product, price, distribution and promotion), two specific components of the online area: interactivity and how to achieve the data as database systems data (Orzan G., Orzan M., 2007). These two components customize online, offering professionals the opportunity to develop the activities they undertake.

An important role regarding the online communication belongs to the used technologies (Schultz, 1996). In this way, besides the traditional elements existent in this moment on the markets (search, websites, portals, webring, forums, blogs, postcards, RSS concentrators) (Gay, Charlesworth, Esen, 2007, p.396), new Web 3.0 technologies appeared (semantic web, Open Source technologies, Open Data Licence, Open Id) that assist the companies, trying to improve contact with the individuals. The online technologies support the investments made by the European funds. In this way, we remark that there is a close link between the investments made by the European funds and the way the marketing activity develops at the destination level.

\section{Methodological framework}

The present study aims to identify the tourists' opinion about the importance of European funded projects in developing tourist destinations. The purpose of this paper is to determine how the results obtained following the investments made are used (through projects financed by the European Union) in the North-West Region (North Transylvania).

This region is one of the eight development regions in Romania and includes 6 counties: Bihor, Bistrita-Nasaud, Cluj, Maramures, SatuMare, Salaj (nord-vest.ro). As regards the European funding, in the period 2007-2013 1,159 projects were submitted under the Regional Operational Program, of which 444 were contracted. As regards the Sectorial Operational Program Economic Competitiveness Increase, in 2013 over 203 projects were implemented (transilvaniabusiness.ro). Tourism development, at Regional Operational Program level, is made by Axis 5, that aims at the achievement of the following objectives: the restoration of cultural heritage, the creation and modernization of related infrastructure; creation, development of tourism infrastructure for the sustainable development of natural resources in order to increase the quality of tourism services and to promote the tourism potential and to create 
the necessary infrastructure to increase Romania's attractiveness as a tourist destination (nord-vest.ro).

In order to correctly analyze the situation, it is necessary to look at the most accurate information about the issue in question (Cătoiu, 2009, p.74). For the analysis made, a number of factors were taken into accounts that contribute to the promotion of this region among tourists. Thus, we wanted to identify the consumer perception on aspects that contribute to improving the way of communication in the analyzed destination. The research on identifying the tourist opinion about the role of the European funding projects promoting the tourist destinations, took place online, Bucharest, between $1^{\text {st }}-20^{\text {th }}$ February 2014, among persons aged 18-45 years who have information on European funds on projects developed in the North West Region (North Transylvania). For the study, a questionnaire was made, that was distributed to the respondents. The research was conducted on a sample of 143 persons. Data from the research were analyzed using the program IBM SPSS Statistics 20.

\section{Research results}

Regarding the results obtained, we mention that, in general, $73.1 \%$ of the total respondents who participated in this study said they are very pleased with the results obtained in the projects funded by the European Union for the development of tourist in North West Region of Romania (North Transylvania). These projects were obtained with the EU support and successfully completed in the Northwest tourist Region of Romania; it can be seen that the main benefit to them and that the majority of respondents have seen it, refers to the rehabilitation of sights of national interest, benefit that $67.9 \%$ of the respondents are very satisfied.

Another important aspect selected by $58.3 \%$ of total persons who participated in the study is the idea of North Transylvania tourist region identity that was generated after the finalisation and implementation of the projects with European funds, in this tourist region. $3.2 \%$ of the respondents are very pleased that the projects undertaken with funding from the European Union have managed to increase the visibility of NorthWest tourist region of Romania among tourists and $52.6 \%$ of the participants in this study considered European funds for these investments were very important for the development of regional tourist authenticity. 1 of 2 respondents said they were very pleased with the implementation of projects funded under European funds because they have promoted the increasing number of jobs in the North-West tourist region of north Transylvania compared with $37.2 \%$ of respondents who believe that European investments were very important for the North- Western part of Romania since they led to maintaining the tradition of the region. Only $15.4 \%$ of those who participated in the study mentioned that EU-funded projects in North Transylvania region are very important for the restoration of monuments of national interest (UNESCO Heritage). 


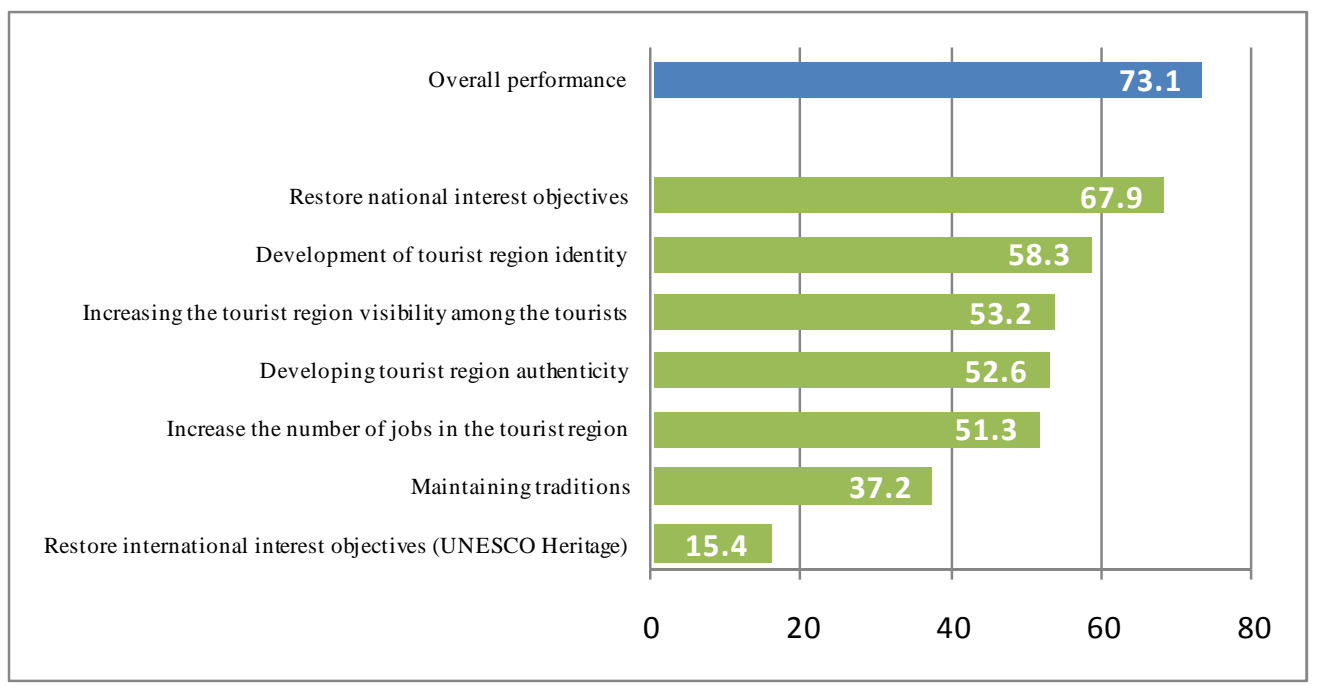

Fig 1. Respondents' satisfaction on the results obtained in the implementation of the projects funded by the European Union

In order to identify the intensity of relationships in the satisfaction of the results obtained in the EU -funded projects in developing the North-West tourist region of Romania (North Transylvania) and its main benefits as well as discovering the most important benefits determining the satisfaction with the results of projects carried out with funding from the European Union, the application of multiple linear regression analysis was made. The dependent variable was represented by the results obtained in the EU-funded projects in developing the North-West tourist region of Romania, while the independent variables were considered as the main benefits of these results obtained by the implementation of projects funded by the European Union (developing tourist region authenticity, development of tourist region identity, restoring international interest objectives (UNESCO Heritage), increasing the tourist region visibility among the tourists, increasing the number of jobs in the tourist region, the rehabilitation of some national interest sights and maintaining traditions).

Table 1: Multiple linear regression model

Model Summary

\begin{tabular}{|c|c|c|c|c|c|c|c|c|c|}
\hline \multirow[b]{2}{*}{ Model } & \multirow[b]{2}{*}{$\mathrm{R}$} & \multirow[b]{2}{*}{$\begin{array}{c}\mathrm{R} \\
\text { Square }\end{array}$} & \multirow[b]{2}{*}{$\begin{array}{l}\text { Adjusted } \\
\text { R Square }\end{array}$} & \multirow{2}{*}{$\begin{array}{l}\text { Std. } \\
\text { Error of } \\
\text { the } \\
\text { Estimate }\end{array}$} & \multicolumn{5}{|c|}{ Change Statistics } \\
\hline & & & & & $\begin{array}{c}\text { R } \\
\text { Square } \\
\text { Change }\end{array}$ & $\begin{array}{c}\mathrm{F} \\
\text { Change }\end{array}$ & df1 & df2 & $\begin{array}{c}\text { Sig. F } \\
\text { Change }\end{array}$ \\
\hline 1 & $.879 a$ & .772 & .761 & .264 & .772 & 71.542 & 7 & 148 & .000 \\
\hline
\end{tabular}

Interpreting the value of the coefficient of determination $\mathbf{R}$ Square (0.772), we can conclude that there is a high and positive correlation between the variables analyzed, which indicates that $77.2 \%$ of the variation of satisfaction regarding the results obtained in the EU -funded projects in the development of the North-West tourist region of Romania is explained by its main component aspects. 
In addition, from the table below (ANOVA), we can capture the existent meaning of the

model, that is, $\mathrm{p}=0.000<0.05$.

Table 2: Multiple linear regression model - ANOVA ANOVA $^{b}$

\begin{tabular}{|c|c|c|c|c|c|c|}
\hline \multicolumn{2}{|c|}{ Model } & $\begin{array}{l}\text { Sum of } \\
\text { Squares }\end{array}$ & $\mathrm{df}$ & $\begin{array}{c}\text { Mean } \\
\text { Square }\end{array}$ & $\mathrm{F}$ & \multirow{2}{*}{$\frac{\text { Sig. }}{.000}$} \\
\hline 1 & Regression & 34.913 & 7 & 4.988 & 71.542 & \\
\hline & Residual & 10.318 & 148 & .070 & & \\
\hline & Total & 45.231 & 155 & & & \\
\hline
\end{tabular}

Noting that the most important benefits of the results obtained in the EU -funded projects in developing the North-West tourist region of Romania largely succeed to explain the variation in the degree of satisfaction on the implementation of these European projects in the tourist region of North Transylvania; we do not consider other variables of influence and we determine the share of each benefit in part in explaining the overall satisfaction on these European projects implemented. The values of the final shares for each component module in part can be found in the last column in the table below.

Table 3: Multiple linear regression model - Coefficients

Coefficients $^{\mathrm{a}}$

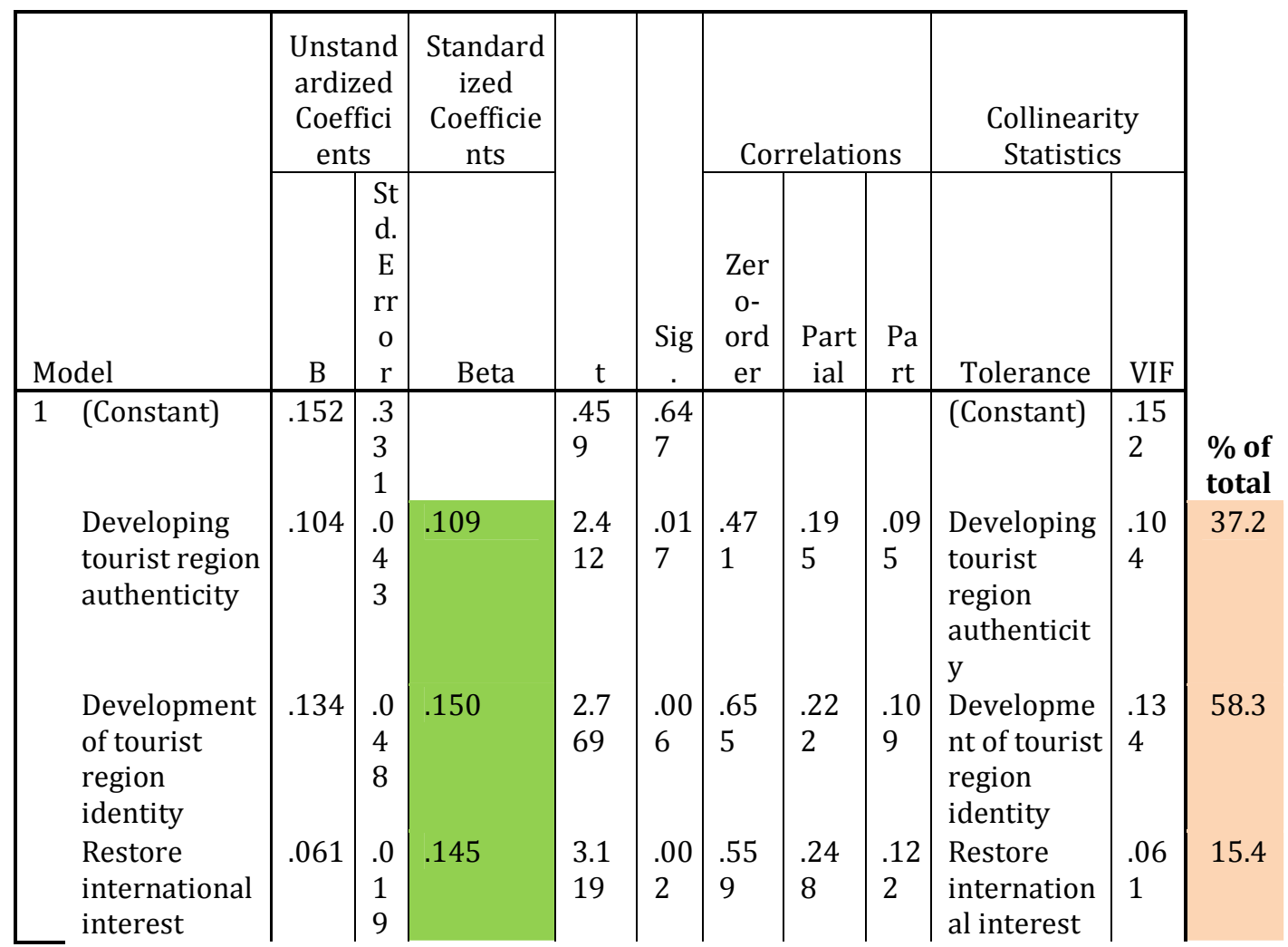

Anamaria - Cătălina Radu, Andra Ileana Dobrescu, Mihai Cristian Orzan and Larisa Boboc (2015), Journal of Economic Studies and Research, DOI: 10.5171/2015. 780380 


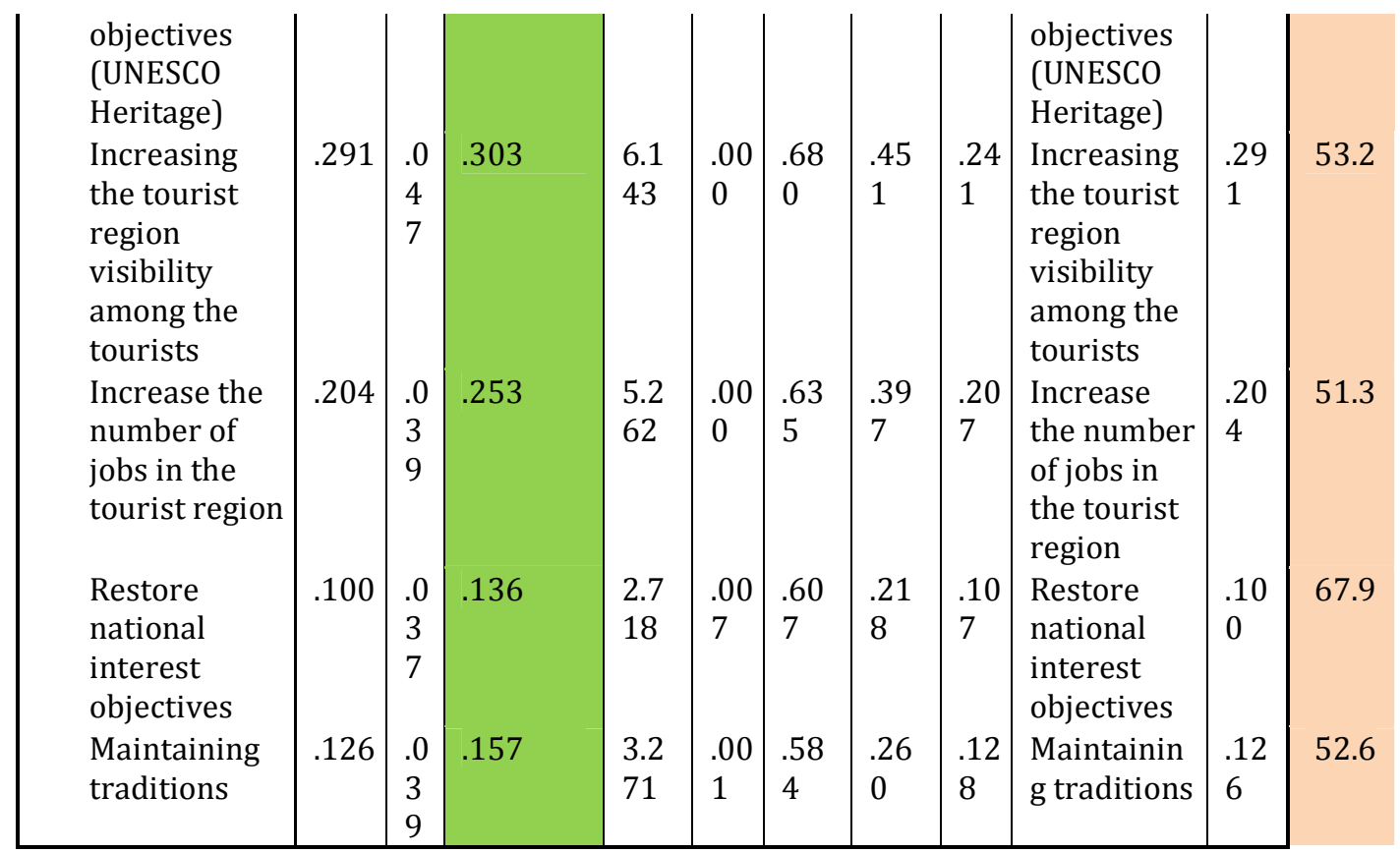

From the figure below you can see that the attribute "increasing the tourist region visibility among tourists" captures the highest performance of the component aspects obtained in the EU-funded projects in developing the North-West tourist region of Romania, and the most attributed of great importance to the respondents who participated in the study, the parameters that it ranks as the most powerful key driver in determining respondents' satisfaction on these European projects. Another benefit (generated following the implementation of projects funded by the European Union in the analyzed tourist region) that showed a high importance among the respondents and increased performance is the "increasing the number of jobs in the tourist region".
"The development of tourist region identity" and " the rehabilitation of monuments of national interest" should be more strongly promoted because they showed a high performance among the main aspects of the results obtained from the implementation of EU-funded projects in the tourist region of North Transylvania but they are not considered to be significant among the respondents. If the results of the European projects that were completed in the North West tourist region of Romania, aspects such as "rehabilitation of some international interest sights (UNESCO Heritage)" and "development of tourist region authenticity" recorded a low importance among the persons who participated in this study, as well not just a high performance. 


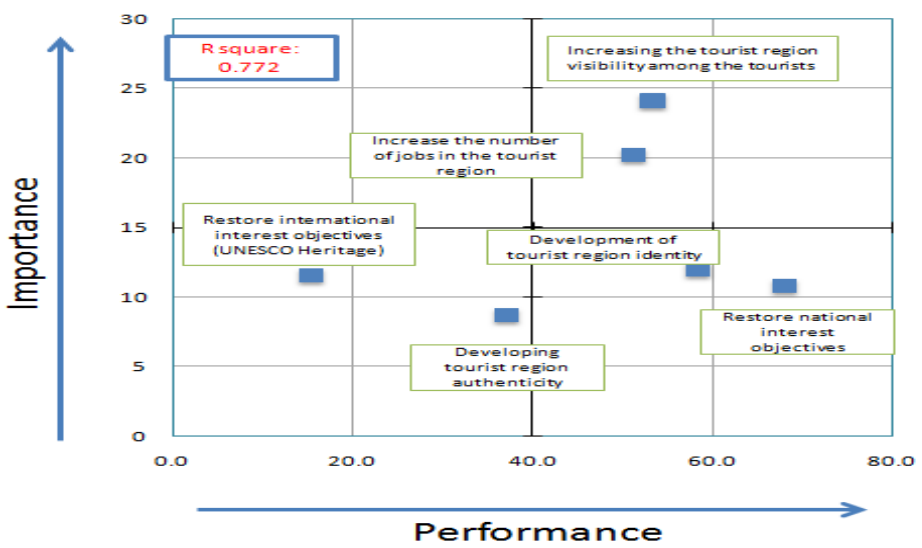

Fig 2. Performance versus importance regarding the main components found at the level of the European Union funded projects

Regarding the listing of the main projects carried out using EU funding in order to develop the North -West tourist Region of Romania (North Transylvania), the majority of the respondents identified: spa park in North West Region (62.6 \%), followed by project of rehabilitation, modernization and equipment of the hotel Bradet in Borsa locality $(56.2 \%)$ and $55.9 \%$ by the mention of all respondents to the tourist complex "Sugatag Holiday Tour" located in Ocna Sugatag. 52.4\% of those who participated in this study said that the project of modernization and equipment with furniture of Borsa chalet was found among those achieved through EU funding for developing the tourist region of North Transylvania, while the project of rehabilitation and equipment of the treatment base and facilities of hotel Parc in Tinca was identified by $38.3 \%$ of the respondents. The indoor swimming pool in Baisoara was mentioned by $28.4 \%$ of the respondents as being achieved through a project with European funding, compared with $12.7 \%$ of the respondents who heard of the project to modernize the tourism base of SC TURISM PALTINIS CERBULUI SRL in Borsa locality as being the result of implementing a project with funding received from the European Union.

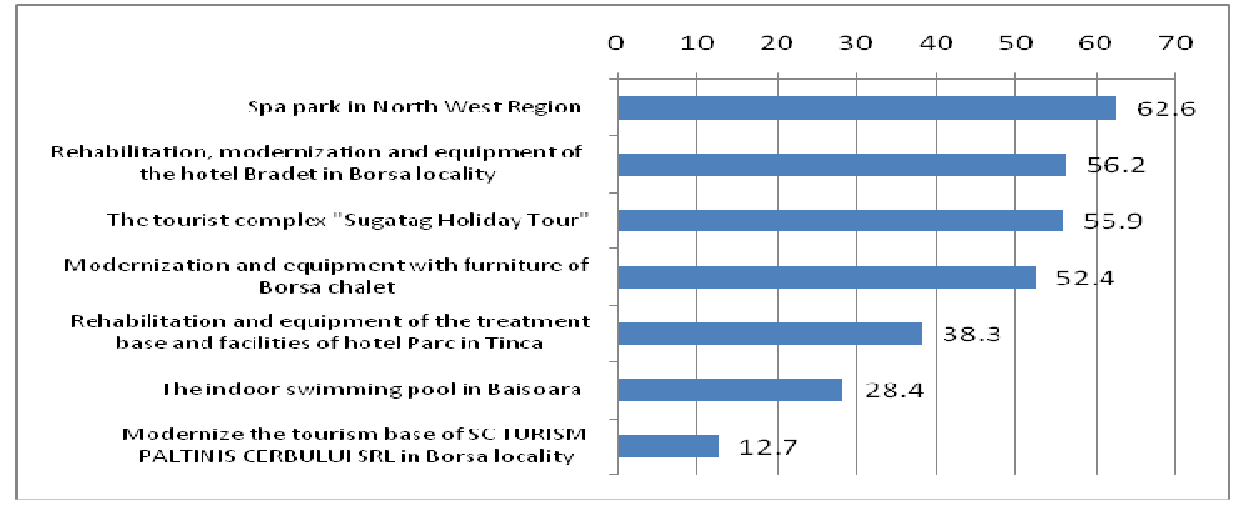

Fig 3. The main projects funded by the European Union which were listed by the respondents 
The main means of informing the respondents about the implementation of the projects funded by the European Union in order to develop the North -West tourist region of Romania is represented by the local and central authority of each component county (78.5\%). 1 of 2 respondents acknowledges the process of European projects in the tourist region analyzed through the local media, while $34.2 \%$ of all surveyed persons learned of this through friends, relatives, colleagues.

$27.6 \%$ of the respondents accessed information websites regarding such
European projects for the development of the tourist region of Northern Transylvania, compared with $23.7 \%$ of the study participants who found more information through the television on these projects. Only $15.8 \%$ of the total respondents said that they found information about the European projects by banners placed in locations where projects are implemented, and $15.3 \%$ heard on the radio information on the implementation of EU-funded projects in the development of North West tourist region of Romania.

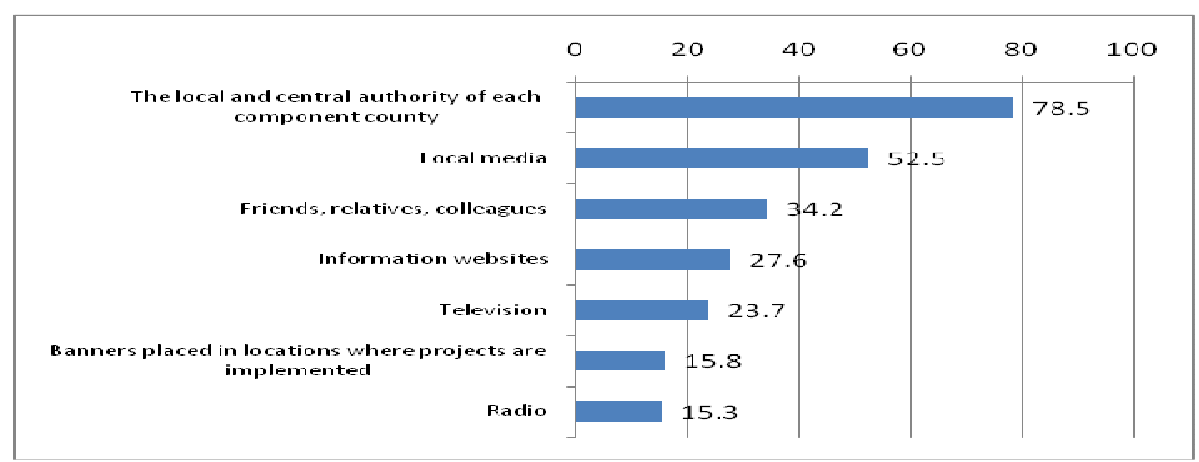

Fig 4. Information sources used by the respondents in order to document regarding the EU funded projects in North-West Region of Romania

Overall, most respondents (71.8\%) declared to be very pleased with the presence of this tourist region of North Transylvania in the online area. By analyzing the main aspects relating the presence in the online area of the North-West tourist Region of Romania, we notice that most persons who participated in the study $(73.1 \%)$ are very satisfied with the manner in which the information transmitted regarding the tourist region are included on representative sites of tourism. $64.1 \%$ of all respondents have greatly appreciated the fact that the analyzed tourist region is visible online through YouTube videos, which present successful projects funded by Regi o. These provide greater transparency of the tourist region. The tourists appreciated also the tourist region page, on social networks, which is presented in an attractive way.

Over half of the total participating persons believe that information transmitted via blog sites is very important in shaping a more realistic image of the tourist region of North Transylvania. Furthermore, they believe that through forums, clear and concise information is presented about the tourist region. For 48.7 $\%$ of the respondents considered that the site with the tourist region presentation is well structured. 


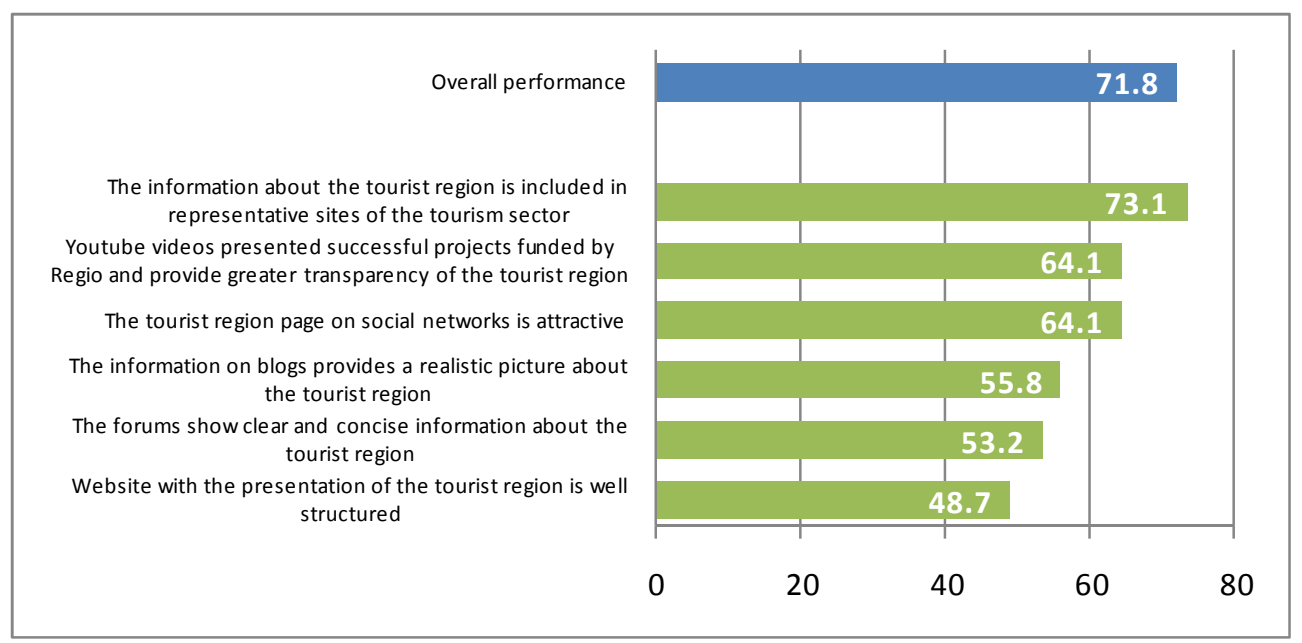

Fig 5. Respondents satisfaction level regarding the presence of North-West Region in online area

In order to observe the intensity of the correlations between the level of satisfaction of the respondents regarding the presence of North-West tourist region of Romania in the online area and the most representative aspects of its presence in the online area, a multiple linear regression type analysis was made. The dependent variable was represented by the presence of the North West tourist region of Romania in the online area, while the independent variables were considered as the most important aspects of the presence of the North -West Tourist Region of Romania in the online area (website with the presentation of the tourist region is well structured, the information about the tourist region is included in representative sites of the tourism sector, the tourist region page on social networks is attractive, the forums show clear and concise information about the tourist region, YouTube videos presented successful projects funded by Regio and provide greater transparency of the tourist region and the information on blogs provides a realistic picture about the tourist region) .

Table 4: Multiple linear regression model

Model Summary

\begin{tabular}{|c|c|c|c|c|c|c|c|c|c|}
\hline \multirow[b]{2}{*}{ Model } & \multirow[b]{2}{*}{$\mathrm{R}$} & \multirow[b]{2}{*}{$\begin{array}{c}\mathrm{R} \\
\text { Square }\end{array}$} & \multirow[b]{2}{*}{$\begin{array}{l}\text { Adjusted } \\
\text { R Square }\end{array}$} & \multirow{2}{*}{$\begin{array}{c}\text { Std. } \\
\text { Error of } \\
\text { the } \\
\text { Estimate }\end{array}$} & \multicolumn{5}{|c|}{ Change Statistics } \\
\hline & & & & & $\begin{array}{c}\text { R } \\
\text { Square } \\
\text { Change }\end{array}$ & $\begin{array}{c}\mathrm{F} \\
\text { Change }\end{array}$ & df1 & $\mathrm{df} 2$ & $\begin{array}{c}\text { Sig. F } \\
\text { Change }\end{array}$ \\
\hline 1 & $.835^{\mathrm{a}}$ & .697 & .684 & .290 & .697 & 56.992 & 6 & 149 & .000 \\
\hline
\end{tabular}

Analyzing the coefficient of determination $\mathbf{R}$ Square (0697), we can capture a high and positive correlation between the analyzed variables, that is $69.7 \%$ of the variation in satisfaction of the respondents regarding the presence of the North-West tourist region of Romania in the online area is explained by the most representative aspects of this region in the online area which were introduced in the model. In addition, noting the analysis of the 
variant (ANOVA), we conclude that the model is significant, having $\mathrm{p}=0.000<0.05$.

Table 5: Multiple linear regression model - ANOVA ANOVA $^{b}$

\begin{tabular}{|c|c|c|c|c|c|c|}
\hline \multicolumn{2}{|c|}{ Model } & $\begin{array}{c}\text { Sum of } \\
\text { Squares }\end{array}$ & $\mathrm{df}$ & $\begin{array}{c}\text { Mean } \\
\text { Square }\end{array}$ & $\mathrm{F}$ & Sig. \\
\hline \multirow[t]{3}{*}{1} & Regression & 28.718 & 6 & \multirow{3}{*}{$\begin{array}{r}4.786 \\
.084\end{array}$} & \multirow[t]{3}{*}{56.992} & \multirow[t]{3}{*}{$.000^{\mathrm{a}}$} \\
\hline & Residual & 12.513 & 149 & & & \\
\hline & Total & 41.231 & 155 & & & \\
\hline
\end{tabular}

Noting that the most important features of the module are able to explain a high proportion of respondents satisfaction variation regarding the presence of the North -West tourist Region of Romania in the online area, the next step is to identify the share of each component separately in determining the general satisfaction regarding the presence of analyzed tourist region in this online area, eliminating the influence of any other features. The values of the final share for each characteristic module separately can be found in the last column in the table below.

Table 6: Multiple linear regression model - Coefficients Coefficients ${ }^{\mathrm{a}}$

\begin{tabular}{|c|c|c|c|c|c|c|c|c|c|c|c|}
\hline \multirow[b]{2}{*}{ Model } & \multicolumn{2}{|c|}{$\begin{array}{l}\text { Unstanda } \\
\text { rdized } \\
\text { Coefficien } \\
\text { ts }\end{array}$} & $\begin{array}{c}\text { Stand } \\
\text { ardiz } \\
\text { ed } \\
\text { Coeffi } \\
\text { cient } \\
\text { s }\end{array}$ & & & \multicolumn{3}{|c|}{ Correlations } & \multicolumn{2}{|c|}{$\begin{array}{c}\text { Collinearity } \\
\text { Statistics }\end{array}$} & \\
\hline & $\mathrm{B}$ & $\begin{array}{l}\text { Std. } \\
\text { Err } \\
\text { or } \\
\end{array}$ & Beta & $\mathrm{t}$ & Sig. & $\begin{array}{l}\text { Zero- } \\
\text { order }\end{array}$ & $\begin{array}{c}\text { Part } \\
\text { ial }\end{array}$ & Part & $\begin{array}{c}\text { Toleranc } \\
\mathrm{e}\end{array}$ & VIF & $\begin{array}{l}\% \text { o } \\
\text { total }\end{array}$ \\
\hline $\begin{array}{l}\text { (Consta } \\
\text { nt) }\end{array}$ & $\begin{array}{r}- \\
.08 \\
0\end{array}$ & $\begin{array}{r}.38 \\
3\end{array}$ & & -.208 & .835 & & & & $\begin{array}{l}\text { (Consta } \\
\text { nt) }\end{array}$ & -.080 & \\
\hline $\begin{array}{l}\text { The } \\
\text { informat } \\
\text { ion } \\
\text { about } \\
\text { the } \\
\text { tourist } \\
\text { region is } \\
\text { included } \\
\text { in } \\
\text { represen } \\
\text { tative } \\
\text { sites of }\end{array}$ & $\begin{array}{r}.36 \\
0\end{array}$ & $\begin{array}{r}.05 \\
8\end{array}$ & .377 & 6.168 & .000 & .723 & $\begin{array}{r}.45 \\
1\end{array}$ & .278 & $\begin{array}{l}\text { The } \\
\text { informat } \\
\text { ion } \\
\text { about } \\
\text { the } \\
\text { tourist } \\
\text { region is } \\
\text { included } \\
\text { in } \\
\text { represe } \\
\text { ntative } \\
\text { sites of }\end{array}$ & .360 & $\begin{array}{c}30 . \\
4\end{array}$ \\
\hline
\end{tabular}

Anamaria - Cătălina Radu, Andra Ileana Dobrescu, Mihai Cristian Orzan and Larisa Boboc (2015), Journal of Economic Studies and Research, DOI: 10.5171/2015. 780380 


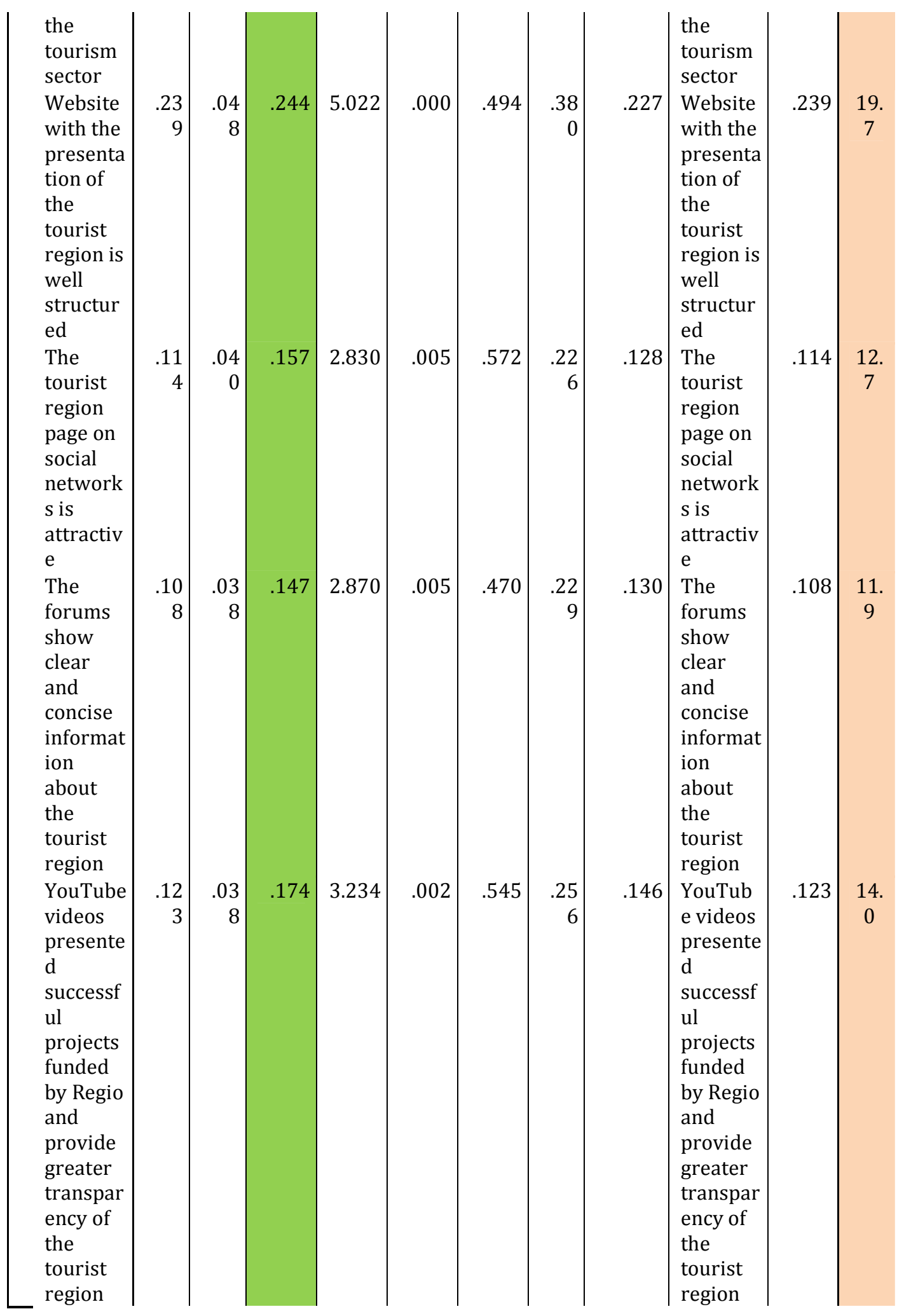

Anamaria - Cătălina Radu, Andra Ileana Dobrescu, Mihai Cristian Orzan and Larisa Boboc (2015), Journal of Economic Studies and Research, DOI: 10.5171/2015. 780380 


\begin{tabular}{|c|c|c|c|c|c|c|c|c|c|c|c|}
\hline $\begin{array}{l}\text { The } \\
\text { informat } \\
\text { ion on } \\
\text { blogs } \\
\text { provides } \\
\text { a } \\
\text { realistic } \\
\text { picture } \\
\text { about } \\
\text { the } \\
\text { tourist } \\
\text { region }\end{array}$ & $\begin{array}{r}.09 \\
0\end{array}$ & $\begin{array}{r}.03 \\
0\end{array}$ & .141 & 2.983 & .003 & .351 & $\begin{array}{r}.23 \\
7\end{array}$ & .135 & $\begin{array}{l}\text { The } \\
\text { informat } \\
\text { ion on } \\
\text { blogs } \\
\text { provides } \\
\text { a } \\
\text { realistic } \\
\text { picture } \\
\text { about } \\
\text { the } \\
\text { tourist } \\
\text { region }\end{array}$ & .090 & $\begin{array}{c}11 . \\
3\end{array}$ \\
\hline
\end{tabular}

From the figure below we can see that "the information about the analyzed tourist region which is included in representative sites of the tourism sector" showed a high performance in the online area and an increased importance received from the respondents who participated in the study. These essential parameters classify it as the strongest key driver in terms of the presence of the tourist region of North Transylvania in the online area.

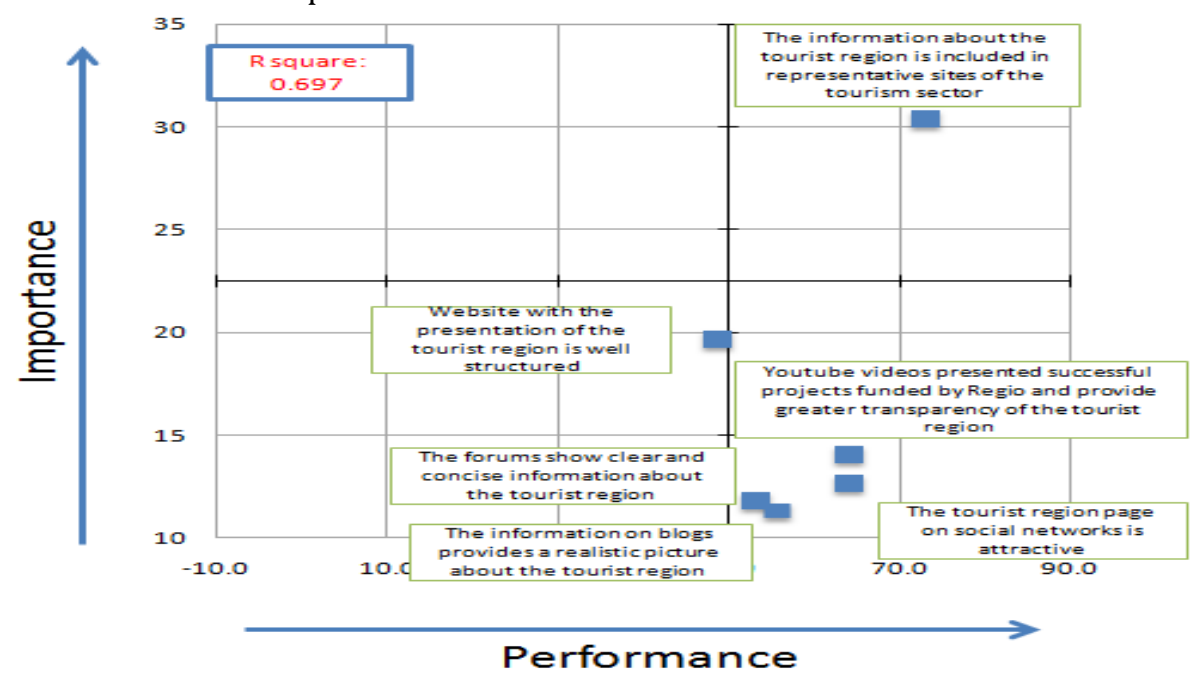

Fig.6. Performance versus importance regarding the main components related to the presence of North-West Region in online area

The aspect on the website presenting the analyzed tourist region, managed to win high performance and a moderate importance among the respondents. The characteristics which recorded a high performance are moderate but important: videos on YouTube which present successful projects funded by Regio, forums, websites and blogs, as well as the region's page on social networks.

\section{Research limits}

Regarding the limits identified in the study, we mention that the research was conducted on a small number of respondents (143) that does not allow us to extrapolate the data obtained on the community studied. In order to have an overview of how the tourist destinations are valued which were funded from European funds; further research must

Anamaria - Cătălina Radu, Andra Ileana Dobrescu, Mihai Cristian Orzan and Larisa Boboc (2015), Journal of Economic Studies and Research, DOI: 10.5171/2015. 780380 
be made, both quantitative and qualitative nature that would give us an overview of the problem analyzed.

Another limitation of the research refers to the fact that the questionnaire was distributed online, which does not offer us the completion by the target audience. Moreover, there may be people who identify with the community investigated but could not access the questionnaire posted on the platform. In order to improve the results, a field research can be made among the target audience to certify or to contradict the above. The future research would need to have as a starting point the results of this study. In addition, it should be conducted on representative samples that give us a much clearer picture of how the investments made through funds are valued.

\section{Conclusions}

From the research made by this study, we observed that the majority of respondents who participated said they are very pleased with the results obtained in the course of the projects funded by the European Union for the development of the North-West tourist region of Romania. The main benefit of implementing these projects is the increase of tourist region visibility among the tourists. It recorded both the highest performance and highest importance among the target audience.

In the research, we observed that the main project achieved through the financial contribution from the European Union for the development of the North-West tourist region of Romania mentioned by most respondents is: Spa Park in the North West Region. Besides this, other sights were mentioned too, but their share is much lower. Regarding the sources of information used by the respondents to research on EU-funded projects in the North - West Region it was noted that most respondents collected information through local authorities.
Analyzing this tourist region of North Transylvania in the online area, the majority of respondents say they are very satisfied of how this region can be found in the online area. Moreover, the strongest key driver of this tourist region of North Transylvania in the online area is the information provided by specialized websites. This aspect managed to record a high performance in the online area and an increased importance received from the respondents who participated in the study.

\section{Acknowledgement}

This work was cofinanced from the European Social Fund through Sectoral Operational Programme Human Resources Development 2007-2013, project number POSDRU/159/1.5/S/134197 „Performance and excellence in doctoral and postdoctoral research in Romanian economics science domain".

\section{References}

1.Catoiu, I. (coord.). (2009), Cercetări de marketing - Tratat, Uranus, Bucharest;

2.Christiansen, T. (2001), 'Intra-institutional politics and inter-institutional relations in the EU: towards coherent governance?, 'Journal of European Public Policy, 8 (5), 747-769;

3.Gay, R., Charlesworth, A., Esen, R. (2007), 'Online marketing: a customer-led approach', Oxford University Press, Oxford;

4.Orzan, G. (2001), Sisteme informatice de marketing, Uranus, Bucharest;

5.Orzan, G., Orzan, M. (2007), Cybermarketing, Uranus, Bucharest;

6.Sarker, MAH., Aimin W., Begum S. (2012), 'Investigating the Impact of Marketing Mix Elements on Tourists 'Satisfaction: An Empirical Study on East Lake, ' European Journal of Business and Management, 4 (7); 
7.Schultz, DE., Tannenbaum, SI., Lauterborn, RE. (1993), Integrated Marketing Communications: Pulling It Together and Making It Work, NTC Publishing Group, Illinois;

Stancioiu, AF., Baltescu, C., Vladoi, AD.,

8.Pargaru, I., Nicula, V. (2011), 'Transylvania Romanian Tourism Micro-destination,'
Theoretical and Applied Economics, 17(5), 147-158;

9.fonduri-ue.ro;

10.www. finantare.ro;

11.www. fonduri-structurale.ro;

12.www.nord-vest.ro;

13.www. transilvaniabusiness.ro

Anamaria - Cătălina Radu, Andra Ileana Dobrescu, Mihai Cristian Orzan and Larisa Boboc (2015), Journal of Economic Studies and Research, DOI: 10.5171/2015. 780380 